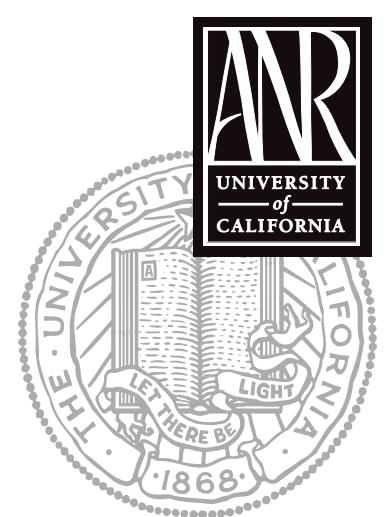

UNIVERSITY OF CALIFORNIA

Division of Agriculture and Natural Resources http://anrcatalog.ucdavis.edu

\title{
Pesticide Choice:
}

\section{Best Management Practice (BMP) for Protecting Surface Water Quality in Agriculture}

RACHAEL LONG, University of California Cooperative Extension Farm Advisor, Yolo County; JAY GAN, Extension Specialist and Professor of Environmental Chemistry, University of California, Riverside; MARY NETT, Consultant, Water Quality Consulting, Colorado Springs, Colorado.

Pesticides are one type of pollutant found in California's surface waters at levels that may be harmful to the aquatic ecosystem. When toxicity occurs, pesticide loadings and surface water pesticide concentrations must be reduced to levels that are not harmful to aquatic life. Factors affecting the potential for a pesticide to move "offsite" from a treated area include field soil properties, climate, grower management practices, and the physical and chemical properties of the active ingredient. This publication provides information to assist pesticide users in evaluating their choice of pesticide products on the basis of the potential to impact surface water quality.

\section{PESTICIDE PROPERTIES AFFECTING TRANSPORT IN WATER}

The likelihood that a pesticide will move in irrigation or stormwater runoff from the site of application depends in large part on the properties of the active ingredient (a.i.), including the pesticide's field dissipation half-life, adsorption coefficient $\left(\mathrm{K}_{\mathrm{oc}}\right)$, and aqueous solubility. Field dissipation half-life is the time required for half of a given quantity of a formulated pesticide to degrade or dissipate from the soil. In general, pesticides that remain in the field for many weeks after treatment (i.e., halflife $>40$ days) are more available to move in runoff because they last the longest in the environment.

The $\mathrm{K}_{\mathrm{oc}}$ is the soil adsorption coefficient for the pesticide, which often depends on the pesticide's hydrophobicity. The larger the $\mathrm{K}_{\mathrm{oc}}$ value, the more strongly the pesticide adsorbs to soil. $\mathrm{K}_{\mathrm{oc}}$ determines how a pesticide moves in runoff. A pesticide with a low $\mathrm{K}_{\mathrm{oc}}$ (i.e., weak adsorption) and high solubility will move in the dissolved form, while a pesticide with high $\mathrm{K}_{\mathrm{oc}}$ (i.e., strong adsorption) will move primarily by associating itself with eroded soil or sediment particles.

Water solubility is the amount of pesticide that can be dissolved per liter of water. As solubility increases, $\mathrm{K}_{\mathrm{oc}}$ usually decreases. However, there are exceptions to this general rule. For example, glyphosate (the active ingredient of Roundup) is highly water soluble, but adsorbs strongly to soil and does not move in water.

The $\mathrm{K}_{\mathrm{oc}}$, solubility, and half-life values for California-registered insecticides, miticides, fungicides, and herbicides are given in tables 1 through 4 . The physicochemical data in these tables were extracted from USDA-ARS 2004 and PesticideWise 2004.

\section{AQUATIC TOXICITY OF PESTICIDES}

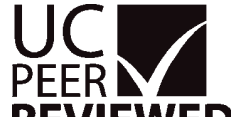

Pesticides differ in their degree of toxicity to aquatic life. In general, insecticides tend to have high toxicity to fish and invertebrates, while some herbicides have high toxicity to aquatic plants (i.e., phytotoxicity). The standard indicator species that the U.S. 
Table 1. Key pesticide properties influencing the potential for insecticides to move in runoff

\begin{tabular}{|c|c|c|c|c|}
\hline $\begin{array}{l}\text { Insecticide } \\
\text { active ingredient } \\
\text { (Common name) }\end{array}$ & $\begin{array}{c}\text { Solubility } \\
(\mathrm{mg} / \mathrm{L})^{*}\end{array}$ & $\mathrm{Koc}^{+}$ & $\begin{array}{c}\text { Field } \\
\text { dissipation } \\
\text { half-life } \\
\text { (days) }^{*}\end{array}$ & $\begin{array}{l}\text { Aquatic } \\
\text { toxicity }\end{array}$ \\
\hline abamectin & 5 & 5,000 & 28 & high \\
\hline acephate & 818,000 & 2 & 6 & moderate \\
\hline azinphosmethyl & 28 & 940 & 10 & very high \\
\hline bifenthrin & 0.0001 & 237,000 & 26 & very high \\
\hline carbaryl & 110 & 288 & 14 & moderate \\
\hline carbofuran & 350 & 46 & 50 & high \\
\hline chlorpyrifos & 1.18 & 9930 & 43 & extremely high \\
\hline cyfluthrin & 0.02 & 100,000 & 22 & extremely high \\
\hline cypermethrin & 0.004 & 61,000 & 77 & very high \\
\hline diazinon & 60 & 1,520 & 40 & very high \\
\hline diflubenzuron & 0.08 & 8,700 & 10 & very low \\
\hline dimethoate & 39,800 & 20 & 7 & high \\
\hline disulfoton & 12 & 600 & 30 & high \\
\hline endosulfan & 0.32 & 12,400 & 60 & very high \\
\hline esfenvalerate & 0.0002 & 5,300 & 42 & very high \\
\hline fenpropathrin & 0.014 & 5,000 & 14 & high \\
\hline fipronil & 2 & 838 & 96 & very high \\
\hline imidacloprid & 580 & 440 & 127 & very low \\
\hline lambda-cyhalothrin & 0.005 & 180,000 & 30 & very high \\
\hline malathion & 130 & 1,200 & 9 & extremely high \\
\hline methamidophos & $1,000,000$ & 5 & 6 & high \\
\hline methidathion & 220 & 400 & 7 & very high \\
\hline methomyl & 58,000 & 72 & 30 & high \\
\hline methyl parathion & 55 & 6,300 & 10 & very high \\
\hline naled & 2,000 & 180 & 1 & very high \\
\hline oxamyl & 282,000 & 25 & 4 & moderate \\
\hline oxydemeton-me & $1,000,000$ & 10 & 10 & moderate \\
\hline permethrin & 0.006 & 100,000 & 42 & very high \\
\hline phorate & 22 & 1,000 & 37 & very high \\
\hline phosmet & 20 & 668 & 14 & very high \\
\hline profenofos & 28 & 2,000 & 9 & moderate \\
\hline spinosad & 89 & 16,420 & 0.4 & very low \\
\hline tebufenozide & 0.83 & 389 & 348 & very low \\
\hline thiodicarb & 19.1 & 351 & 5 & high \\
\hline tralomethrin & 0.001 & 100,000 & 27 & very high \\
\hline \multicolumn{5}{|c|}{$\begin{array}{l}\text { Sources: PAN 2004; PesticideWise 2004; USDA-ARS } 2004 . \\
\text { Notes: } \\
\text { *Amount of pesticide able to be dissolved in water. } \\
\text { †Adsorption coefficient normalized over soil organic carbon content. } \\
\text { †Time required for 50\% of the chemical to disappear from the soil following treatment. } \\
\text { SBased on toxicity evaluation of water fleas (Daphnia magna or Ceriodaphnia } \\
\text { dubia), rainbow trout (Oncorhynchus mykiss), or phytoplankton (typically Selenastrum } \\
\text { capricornatum). See table } 5 \text {. }\end{array}$} \\
\hline
\end{tabular}

Table 2. Key pesticide properties influencing the potential for miticides to move in runoff

\begin{tabular}{|l|c|c|c|c|}
\hline $\begin{array}{l}\text { Miticide active ingredient } \\
\text { (Common name) }\end{array}$ & $\begin{array}{c}\text { Solubility } \\
\text { (mg/L) }\end{array}$ & \multicolumn{1}{|c|}{$\begin{array}{c}\text { Field } \\
\text { Koc }\end{array}$} & $\begin{array}{c}{ }^{*} \\
\text { dissipation } \\
\text { half-life (days) }\end{array}$ & $\begin{array}{c}\text { Aquatic } \\
\text { toxicity }\end{array}$ \\
\hline avermectin & 5 & 5,000 & 28 & high \\
\hline bifenazate & 4 & 4,600 & 5 & moderate \\
\hline clofentezine & 0.0025 & 45,300 & 40 & high \\
\hline dicofol & 0.8 & 6,064 & 57 & high \\
\hline fenbutatin oxide & 0.0127 & 2,721 & 95 & very high \\
\hline formetanate hydrochloride & 820,000 & 275 & 9 & high \\
\hline hexythiazox & 0.5 & 6,200 & 30 & moderate \\
\hline propargite & 0.6 & 41,000 & 84 & high \\
\hline pyridaben & 0.012 & 110,000 & 86 & very high \\
\hline
\end{tabular}

Sources: PAN 2004; PesticideWise 2004; USDA-ARS 2004.

Notes:

*Amount of pesticide able to be dissolved in water.

${ }^{\dagger}$ Adsorption coefficient normalized over soil organic carbon content.

*Time required for $50 \%$ of the chemical to disappear from the soil following treatment.

sBased on toxicity evaluation of water fleas (Daphnia magna or Ceriodaphnia dubia), rainbow trout

(Oncorhynchus mykiss), or phytoplankton (typically Selenastrum capricornatum). See table 5. (waterfleas, scud), fish, and phytoplankton (green algae) (US EPA 2002). Acute effect levels are typically based on $\mathrm{LC}_{50}$ (the dose of a pesticide that kills half the test organisms) or $\mathrm{EC}_{50}$ (the dose that causes some sublethal effect in half the test organisms). Aquatic toxicity rankings from extremely low to extremely high were used to determine an appropriate risk category (table 5). Data were extracted from the US EPA AQUIRE database (PAN 2004). When a range of values was given for a specific effect, the lowest concentration was generally selected for the toxicity ranking. The toxicity for the most sensitive indicator species was then used to rank the overall aquatic toxicity. The overall aquatic toxicity rankings for California registered insecticides, miticides, herbicides, and fungicides are listed in the last column in

Table 3. Key pesticide properties influencing the potential for fungicides to move in runoff

\begin{tabular}{|c|c|c|c|c|}
\hline $\begin{array}{l}\text { Fungicide active } \\
\text { ingredient } \\
\text { (Common name) }\end{array}$ & $\begin{array}{l}\text { Solubility } \\
\text { (mg/L)* }^{*}\end{array}$ & $\mathrm{~K}_{\mathrm{oc}}{ }^{\dagger}$ & $\begin{array}{c}\text { Field } \\
\text { dissipation } \\
\text { half-life (days) }\end{array}$ & $\begin{array}{l}\text { Aquatic } \\
\text { toxicity }\end{array}$ \\
\hline azoxystrobin & 7 & 1,590 & 65 & very high \\
\hline captan & 5 & 200 & 3 & low \\
\hline carboxin & 195 & 260 & 6 & moderate \\
\hline chlorothalonil & 0.6 & 5,000 & 30 & high \\
\hline copper sulfate & 10,000 & 30 & 4 & very high \\
\hline cymoxanil & 780 & 110 & 5 & moderate \\
\hline cyprodinil & 13 & 1,000 & 50 & moderate \\
\hline dicloran & 7 & 1,000 & 10 & moderate \\
\hline dodine & 700 & 100,000 & 20 & high \\
\hline fenarimol & 14 & 760 & 360 & low \\
\hline fenbuconazole & 38 & 5,776 & 247 & high \\
\hline fosetyl-al & 120,000 & 166 & 1 & low \\
\hline imazalil & 1400 & 4,000 & 150 & moderate \\
\hline iprodione & 14 & 700 & 14 & moderate \\
\hline mancozeb & 6 & 6,000 & 70 & high \\
\hline maneb & 6 & 2,000 & 70 & high \\
\hline myclobutanil & 142 & 500 & 66 & moderate \\
\hline propiconazole & 110 & 1,000 & 110 & high \\
\hline thiabendazole & 50 & 2,500 & 403 & high \\
\hline thiophanate methyl & 3.5 & 1,830 & 6 & moderate \\
\hline thiram & 30 & 670 & 15 & very high \\
\hline triadimefon & 72 & 300 & 26 & moderate \\
\hline triflumizole & 12,500 & 40 & 14 & high \\
\hline vinclozolin & 1,000 & 100 & 20 & moderate \\
\hline ziram & 65 & 400 & 30 & very high \\
\hline \multicolumn{5}{|c|}{$\begin{array}{l}\text { Sources: PAN 2004; PesticideWise 2004; USDA-ARS } 2004 . \\
\text { Notes: } \\
\text { `Amount of pesticide able to be dissolved in water. } \\
\text { } \text { Adsorption coefficient normalized over soil organic carbon content. } \\
\text { tTime required for } 50 \% \text { of the chemical to disappear from the soil following treatment. } \\
\text { sBased on toxicity evaluation of water fleas (Daphnia magna or Ceriodaphnia } \\
\text { dubia), rainbow trout (Oncorhynchus mykiss), or phytoplankton (typically Selenastrum } \\
\text { capricornatum). See table } 5 \text {. }\end{array}$} \\
\hline
\end{tabular}


Table 4. Key pesticide properties influencing the potential for herbicides to move in runoff

\begin{tabular}{|c|c|c|c|c|}
\hline $\begin{array}{l}\text { Herbicide active ingredient } \\
\text { (Common name) }\end{array}$ & Solubility $(\mathrm{mg} / \mathrm{L})^{*}$ & $\mathrm{Koc}^{\dagger}$ & $\begin{array}{l}\text { Field dissipation } \\
\text { half-life (days) }\end{array}$ & Aquatic toxicity ${ }^{\S}$ \\
\hline alachlor & 240 & 124 & 27 & very high \\
\hline atrazine & 33 & 147 & 173 & high \\
\hline benefin & 0.1 & 9,000 & 40 & high \\
\hline bensulide & 6 & 1,000 & 120 & high \\
\hline bentazon sodium & $2,300,000$ & 35 & 27 & moderate \\
\hline bromacil & 700 & 32 & 60 & very high \\
\hline bromoxynil butyrate & 27 & 1,079 & 7 & high \\
\hline clethodim & 5,400 & 10 & 3 & low \\
\hline clopyralid & 9,000 & 36 & 30 & low \\
\hline cyanazine & 155 & 218 & 14 & very high \\
\hline cycloate & 95 & 272 & 27 & moderate \\
\hline $2,4-d$ & 890 & 48 & 10 & moderate \\
\hline 2,4-db (salt) & 46 & 440 & 5 & high \\
\hline dcpa & 0.5 & 5,600 & 100 & moderate \\
\hline dicamba (salt) & 360,000 & 2 & 16 & moderate \\
\hline dichlobenil & 21 & 400 & 60 & high \\
\hline diclofop & 0.8 & 16,000 & 20 & high \\
\hline difenzoquat methyl sulfate & 817,000 & 55,000 & 100 & moderate \\
\hline diquat dibromide & 718,000 & $1,000,000$ & 1000 & high \\
\hline dithiopyr & 1 & 800 & 400 & high \\
\hline diuron & 42 & 480 & 90 & very high \\
\hline dsma & 254,000 & 7,000 & 180 & high \\
\hline endothall & 100,000 & 20 & 3 & high \\
\hline eptc & 344 & 200 & 6 & high \\
\hline ethofumesate & 50 & 340 & 30 & moderate \\
\hline fenoxaprop ethyl & 0.9 & 9,490 & 12 & high \\
\hline fluazifop-p-butyl & 2 & 5,700 & 15 & high \\
\hline glufosinate & $1,370,000$ & 100 & 7 & moderate \\
\hline glyphosate & 12,000 & 24,000 & 47 & moderate \\
\hline halosulfuron & 1,630 & 100 & 14 & low \\
\hline hexazinone & 29,800 & 54 & 79 & very high \\
\hline imazapyr & 15,000 & 100 & 90 & very low \\
\hline Imazethapyr & 200,000 & 10 & 90 & low \\
\hline isoxaben & 1 & 1,400 & 100 & high \\
\hline linuron & 75 & 400 & 60 & high \\
\hline mсра & 5 & 1,000 & 25 & high \\
\hline mecoprop & 660,000 & 20 & 21 & moderate \\
\hline metham sodium & 963,000 & 10 & 7 & high \\
\hline metolachlor & 530 & 200 & 90 & moderate \\
\hline metribuzin & 1,000 & 52 & 47 & very high \\
\hline msma & $1,400,000$ & 7,000 & 180 & moderate \\
\hline napropamide & 74 & 400 & 70 & moderate \\
\hline nicosulfuron & 12,000 & 30 & 21 & extremely low \\
\hline norflurazon & 28 & 600 & 90 & very high \\
\hline oryzalin & 2 & 600 & 20 & high \\
\hline oxadiazon & 0.7 & 3,200 & 60 & very high \\
\hline oxyfluorfen & 0.1 & 100,000 & 30 & high \\
\hline paraquat & 620,000 & $1,000,000$ & 1,000 & moderate \\
\hline pebulate & 100 & 430 & 8 & high \\
\hline pendimethalin & 0.3 & 5,000 & 90 & very high \\
\hline prodiamine & 0.01 & 13,000 & 120 & high \\
\hline prometryn & 33 & 400 & 60 & very high \\
\hline propyzamide & 15 & 200 & 60 & high \\
\hline pyrithiobac sodium & 730 & 70 & 60 & very low \\
\hline pyrazon & 400 & 120 & 21 & high \\
\hline rimsulfuron & 7,300 & 47 & 10 & very low \\
\hline sethoxydim & 4,700 & 100 & 5 & high \\
\hline simazine & 6 & 130 & 60 & high \\
\hline thiazopyr & 2 & 400 & 85 & moderate \\
\hline triclopyr (ester) & 23 & 780 & 46 & high \\
\hline trifluralin & 0.3 & 7,200 & 60 & very high \\
\hline
\end{tabular}

Sources: PAN 2004; PesticideWise 2004; USDA-ARS 2004.

Notes:

*Amount of pesticide able to be dissolved in water.

†Adsorption coefficient normalized over soil organic carbon content.

*Time required for $50 \%$ of the chemical to disappear from the soil following treatment.

sBased on toxicity evaluation of water fleas (Daphnia magna or Ceriodaphnia dubia), rainbow trout (Oncorhynchus mykiss), or phytoplankton (typically Selenastrum capricornatum). See table 5. 
Table 5. Basis for aquatic toxicity rankings for California-registered pesticides in tables 1 through 4

$\begin{array}{cc}\text { Aquatic Toxicity }(\mu \mathrm{g} / \mathrm{L}, \mathrm{ppb})^{*} & \begin{array}{c}\text { Risk ranking } \\ \text { extremely high } \\ <0.00014\end{array} \\ <0.14 & \text { very high } \\ <14 & \text { high } \\ <1400 & \text { moderate } \\ <14000 & \text { low } \\ <85000 & \text { very low } \\ >85000 & \text { extremely low }\end{array}$

Source: US EPA 2002.

Notes:

*Based on evaluation of water fleas (Daphnia magna or Ceriodaphnia dubia) toxicity (typically acute $\mathrm{LC}_{50}$, 48-hr test); rainbow trout (Oncorhynchus mykiss) toxicity (typically acute $\mathrm{LC}_{50}, 96$-hr test); or effect on population abundance of the phytoplankton Selenastrum capricornatum (typically $\mathrm{EC}_{50}$ ). tables 1 through 4 . It is important to select a pesticide that has a low toxicity to aquatic life, especially when used near waterbodies.

\section{PESTICIDE RUNOFF RISK}

For each California-registered pesticide active ingredient examined in this publication, $\mathrm{K}_{\mathrm{oc}}$, solubility, and half-life values were used to fit two USDA-NRCS algorithms to determine the pesticide's tendency to move in dissolved form (i.e., solution runoff) or with soil (i.e., adsorption runoff). The potential to move off site, either in solution or with soil, was then categorized into "high" (great potential to move), "intermediate" (moderate potential to move), and "low" (limited potential to move) (tables 6-9). In general, when a pesticide has a relatively long half-life and a large $\mathrm{K}_{\mathrm{oc}}$ and/or low solubility, the potential for adsorption runoff is high. If a pesticide has a relatively long half-life and a small $\mathrm{K}_{\mathrm{oc}}$ and/or high solubility, the potential for solution runoff is high. The runoff potential was then considered together with the aquatic toxicity for a given pesticide to estimate its overall runoff risk. Overall runoff risk in this publication is a product of the runoff potential and the aquatic toxicity; this is listed in the last column in tables 6 through 9 for California-registered insecticides, miticides, fungicides, and herbicides. For example, if a pesticide has a high runoff potential but a low aquatic toxicity, the overall runoff risk is low. If a pesticide has a moderate or high runoff potential but very high aquatic toxicity, the overall runoff risk is high or very high. Pesticides labeled "very high" or "high" in tables 6 through 9 should be used with precautions and/or with proper mitigation practices.

\section{OTHER FACTORS AFFECT- ING PESTICIDE RUNOFF}

The occurrence of pesticide runoff also depends heavily on many other factors, including soil properties, crop production practices, irrigation management, rain events, and pesticide application methods and timing. Soils high in clay and organic matter may adsorb pesticides better than 
Table 7. California-registered miticides ranked by potential to move in solution or as adsorbed particles and overall pesticide runoff risk

\begin{tabular}{l|c|c|c|c}
\hline $\begin{array}{l}\text { Miticide active ingredient } \\
\text { (Common name) }\end{array}$ & Trade name $=$ & Solution runoff potential $^{*}$ & Adsorption runoff potential $^{+}$ & Overall runoff risk $^{\ddagger}$ \\
\hline fenbutatin oxide & Vendex & high & high & very high \\
\hline pyridaben & Pyramite, Nexter & high & high & very high \\
\hline
\end{tabular}

\begin{tabular}{l|c|c|c|c}
\hline clofentezine & Apollo & high & high & high \\
\hline dicofol & Kelthane & high & high & high \\
\hline formetanate hydrochloride & Carzol & high & high & high \\
\hline propargite & Comite, Omite & high & intermediate & high \\
\hline avermectin & Avid, Agri-mek & high & intermediate & moderate \\
\hline \multicolumn{5}{|c|}{ high } \\
\hline hexythiazox & Savey & intermediate & moderate \\
\hline bifenazate & Acramite &
\end{tabular}

Notes:

*Likelihood that the active ingredient will transport from the area of treatment as dissolved chemical in runoff.

'Likelihood that the active ingredient will transport from the area of treatment as attachment to soil or sediment particles in runoff.

‡Overall likelihood to cause negative impact on surface water quality as a product of the runoff potential and the aquatic toxicity of the pesticide.

Table 8. California-registered fungicides ranked by potential to move in solution or as adsorbed particles and overall pesticide runoff risk

\begin{tabular}{|c|c|c|c|c|}
\hline $\begin{array}{l}\text { Fungicide active ingredient } \\
\text { (Common name) }\end{array}$ & Trade name= & $\begin{array}{l}\text { Solution runoff } \\
\text { potential* }\end{array}$ & $\begin{array}{c}\text { Adsorption runoff } \\
\text { potential }^{\dagger}\end{array}$ & Overall runoff risk ${ }^{\ddagger}$ \\
\hline azoxystrobin & Quadris, Abound & high & high & very high \\
\hline copper sulfate & copper sulfate & high & high & very high \\
\hline fenbuconazole & Indar & high & high & high \\
\hline maneb & Maneb & high & high & high \\
\hline propiconazole & Break, Orbit, tilt & high & high & high \\
\hline mancozeb & Dithane & high & high & high \\
\hline thiabendazole & Mertect & high & high & high \\
\hline chlorothalonil & Bravo, Echo & high & intermediate & high \\
\hline thiram & Thiram & intermediate & low & high \\
\hline ziram & Ziram & intermediate & low & high \\
\hline cyprodinil & Vangard & high & high & moderate \\
\hline imazalil & Fungaflor & high & high & moderate \\
\hline myclobutanil & Rally, Laredo & high & intermediate & moderate \\
\hline dicloran & Botran & intermediate & intermediate & moderate \\
\hline thiophanate methyl & Topsin & intermediate & intermediate & moderate \\
\hline carboxin & Vitavax & intermediate & low & moderate \\
\hline cymoxanil & Curzate & intermediate & low & moderate \\
\hline iprodione & Rovral & intermediate & low & moderate \\
\hline triadimefon & Bayleton & intermediate & low & moderate \\
\hline triflumizole & Procure & intermediate & low & moderate \\
\hline vinclozolin & Ronilan & intermediate & low & moderate \\
\hline fenarimol & Rubigan & high & intermediate & low \\
\hline captan & Captan & intermediate & low & low \\
\hline fosetyl-al & Aliette & low & low & low \\
\hline
\end{tabular}

Notes:

* Likelihood that the active ingredient will transport from the area of treatment as dissolved chemical in runoff.

tLikelihood that the active ingredient will transport from the area of treatment as attachment to soil or sediment particles in runoff.

${ }^{\ddagger}$ Overall likelihood to cause negative impact on surface water quality as a product of the runoff potential and the aquatic toxicity of the pesticide. 
Table 9. California-registered herbicides ranked by potential to move in solution or as adsorbed particles and overall pesticide runoff risk

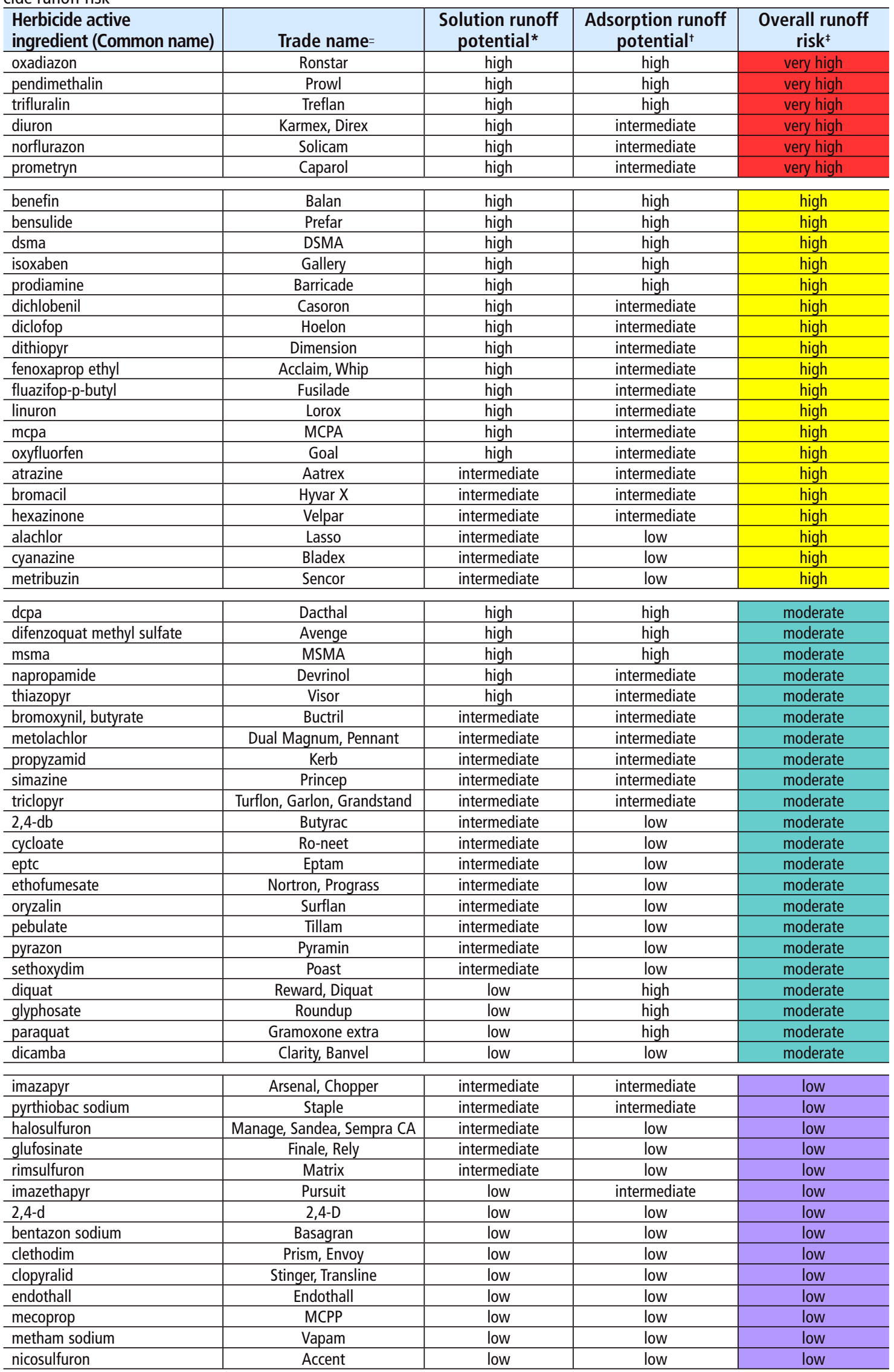

* Likelihood that the active ingredient will transport from the area of treatment as dissolved chemical in runoff.

thikelihood that the active ingredient will transport from the area of treatment as attachment to soil or sediment particles in runoff.

${ }^{\ddagger}$ Overall likelihood to cause negative impact on surface water quality as a product of the runoff potential and the aquatic toxicity of the pesticide. 
sandy soils; however, clay soils can be more prone to pesticide runoff, as they tend to have low water permeability and may allow water to pool on the soil surface. Correct pesticide application rates, accurate equipment calibration, proper application timing, careful handling of pesticides, minimizing drift, establishing buffer zones around waterways, and proper cleanup and disposal of pesticides minimize the potential for runoff problems associated with pesticide use.

To develop effective mitigation practices, pesticide applicators must understand whether a pesticide moves with runoff in solution or as attachment to solids. For instance, although some pesticides (such as pyrethroids) are not likely to move in the dissolved form in runoff water, they can move by attaching to eroded soil particles and can enter surface streams, where they may cause toxicity to sediment organisms. For these pesticides, it is useful to implement practices to reduce sediment transport in irrigation or storm water runoff from pesticide treated areas. One example of an effective management practice is the use of vegetative filter strips, such as grasses or sedges planted along ditches or streams, to help trap sediments. Other examples include tail-water ponds to help slow the flow of water and enable soil particles to settle out, or using polyacrylimide polymers (PAM) to aggregate soil particles, allowing them to precipitate from the water. However, these practices will not be equally effective if used for reducing the runoff of a pesticide moving primarily in solution. Because water movement is the driving force for any pesticide runoff, improving irrigation efficiency and reducing the amount of runoff is essential when applying pesticides that move in solution. Capturing runoff using a tail pond or retention pond allows more time for pesticides to degrade, resulting in reduced pesticide runoff for pesticides moving either in the solution or in the adsorbed phase.

\section{REFERENCES}

PAN 2004. PAN pesticides database: Chemical toxicity studies on aquatic organisms. Pacific Action Network database, http://pesticideinfo.org/Search_Ecotoxicity.jsp.

PesticideWise 2004. University of California Cooperative Extension Water Quality Program, Riverside Web site, http://www.pw.ucr.edu/.

SWRCB 2004. California State Water Resources Control Board Web site, http://www.swrcb.ca.gov

USDA-ARS. 2004. The ARS pesticide properties database. USDA-ARS Crop Systems and Global change Web site, http://www.ars.usda.gov/Services/docs.htm?docid=6433.

US EPA 2002. Methods for measuring the acute toxicity of effluents and receiving waters to freshwater and marine organisms. 5th ed. EPA-821-R-02-012. US EPA Water Science Web site, http://www.epa.gov/waterscience/WET/disk2/. 


\section{FOR MORE INFORMATION}

To order or obtain printed ANR publications and other products, visit the ANR Communication Services online catalog at http://anrcatalog.ucdavis.edu. You can also place orders by mail, phone, or FAX, or request a printed catalog of our products from:

University of California

Agriculture and Natural Resources

Communication Services

6701 San Pablo Avenue, 2nd Floor

Oakland, California 94608-1239

Telephone: (800) 994-8849 or (510) 642-2431

FAX: (510) 643-5470

E-mail inquiries: danrcs@ucdavis.edu

An electronic version of this publication is available on the ANR Communication Services Web site at http://anrcatalog.ucdavis.edu.

\section{Publication 8161}

(C) 2005 by the Regents of the University of California, Division of Agriculture and Natural Resources. All rights reserved.

To simplify information, trade names of products have been used. No endorsement of named or illustrated products is intended, nor is criticism implied of similar products that are not mentioned or illustrated.

The University of California prohibits discrimination or harassment of any person on the basis of race, color, national origin, religion, sex, gender identity, pregnancy (including childbirth, and medical conditions related to pregnancy or childbirth), physical or mental disability, medical condition (cancer-related or genetic characteristics), ancestry, marital status, age, sexual orientation, citizenship, or status as a covered veteran (covered veterans are special disabled veterans, recently separated veterans, Vietnam era veterans, or any other veterans who served on active duty during a war or in a campaign or expedition for which a campaign badge has been authorized) in any of its programs or activities. University policy is intended to be consistent with the provisions of applicable State and Federal laws.

Inquiries regarding the University's nondiscrimination policies may be directed to the Affirmative Action/Staff Personnel Services Director, University of California, Agriculture and Natural Resources, 300 Lakeside Drive, 6th Floor, Oakland, CA 94612-3550 (510) 987-0096. For a free catalog of other publications, call (800) 994-8849. For help downloading this publication, call (530) 297-4445.

This publication has been anonymously peer reviewed for technical accuracy by University of California scientists and other qualified professionals. This review process was managed by the ANR Associate Editor for Pest Management.

pr-11/05-SB/CR

ISBN 978-1-60107-330-3 